\title{
HYDROGEOLOGY OF MANGSRI CAVE, GUNUNGSEWU KARST AREA, JAVA ISLAND, INDONESIA
}

\author{
*Ahmad Cahyadi ${ }^{12}$, Hilary Reinhart ${ }^{2,3}$, Angga Wahyu Ristiawan ${ }^{4}$, Rakhmat Dwi Putra ${ }^{5}$, M. Ainul Labib ${ }^{2}$, \\ Muhammad Naufal ${ }^{1,2}$, Indra Agus Riyanto ${ }^{2}$, Fajri Ramadhan ${ }^{1,2}$, Angga Dwi Laksono ${ }^{5}$ \\ *11Department of Environmental Geography - Universitas Gadjah Mada, Indonesia \\ ${ }^{2}$ Karst Research Group - Universitas Gadjah Mada, Indonesia \\ ${ }^{3}$ Departmen of Regional Development - Universitas Gadjah Mada, Indonesia \\ ${ }^{4}$ Department of Geology Engineering - Universitas Gadjah Mada, Indonesia \\ ${ }^{5}$ Department of Geographical Information Science - Universitas Gadjah Mada, Indonesia \\ ${ }^{6}$ Lentera Geosains - Yogyakarta, Indonesia \\ Email: ahmad.cahyadi@ugm.ac.id
}

*Corresponding Author, Received: February 19, 2021. Revised: March 11, 2021. Accepted: May 10, 2021

\begin{abstract}
The Gunungsewu karst area is not only known for its unique landscape but also its recurring drought events. To meet the water supply, the local population utilizes several water potentials, namely doline pond, spring, and underground river. This study was designed to analyze the hydrogeological conditions of Mbangsri Cave, following its accidental discovery by the community at the end of 2018. The hydrogeological analysis was conducted by geological surveys, which consisted of rocks collection and structural measurements, cave mapping, and recharge area delineation based on remote sensing images acquired by unmanned aerial vehicles. The results showed that Mbangsri Cave, in the hydrogeological perspective, had low water resources potential. It is believed to be the result of (1) relatively small catchment area, (2) a fault in the southern part of Mbangsri Cave, creating a small groundwater basin, and (3) the thin epikarst layer, limiting the water storage.
\end{abstract}

Keywords: Karst, Cave, Hydrogeology, Epikarst, Gunungsewu Karst Area

\section{INTRODUCTION}

Karst is widely known as a landscape frequently encountering droughts due to its unique hydrological conditions. Conduit development as the result of the dissolution process allows surface water to flow rapidly into the underground river system and triggers dry conditions on the surface $[1$, $2,3]$. It often hampers the nearby community from accessing clean water [4].

As discovered by Lehman in 1936, Gunungsewu has a distinctive landscape and is thereby one of the most famous karst areas in Indonesia. Also, some experts affirm that it is peculiarly composed of "stream bread"-shaped hills or kegelkarst. However, Gunungsewu is also popular because of its highly frequent drought events in dry seasons [5] even though it receives averagely high precipitation [6].

In late 2018, news from several Indonesian mass media (Figure 1) reported that the residents of Blado Sub-village, Giritirto Village, Purwosari District, Gunungkidul Regency discovered a cave full of water (Mbangsri Cave) (Figure 2). This subvillage is a cluster of houses that were displaced away from an escarpment after the 2006 earthquake. Unfortunately, the displacement location does not provide sufficient water resources as it only has access to springs with low discharge. Therefore, this discovery is expected to facilitate the provision of local clean water in the future. This study was designed to analyze the hydrogeological system of Mbangsri Cave. It is thought to be an essential reference for future water resource utilization and management in the region [7].

\section{METHODS}

The research data comprised details on regional geology and the catchment or recharge area of Mbangsri Cave. Detailed geological mapping was carried out through field surveys, including rock sampling, geological structure measurement, and conduit observation. The recharge area was identified by cave and ponor survey and detailed topographic mapping using unmanned aerial vehicles (UAVs). A conduit mapping was performed using the Grade 5A Standard of the British Cave Research Association (BCRA). Also, the hydrological condition was gauged by measuring the discharge of the underground river in Mbangsri Cave. 
Temukan Mata Air di Gua, Warga Cunungkidul Ini

\section{Butuh Bantuan Pompa}

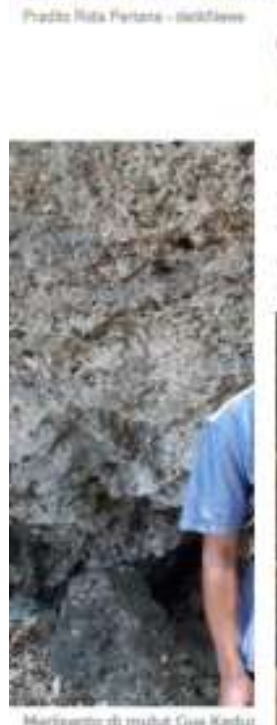

Grunguolu

Kisah Marjianto Temukan Sumber Air

di Dalam Gua Kedung Mbangsri,

Berjalan Merangkak 500 Meter

\section{Kelelawar Beri Petunjuk Warga Gunungkidul Temui Sumber Air}

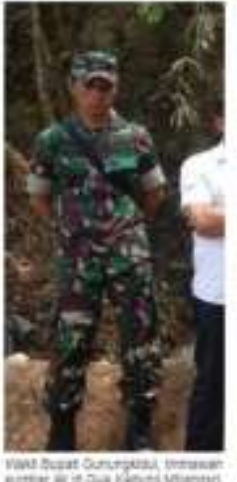

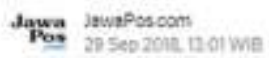

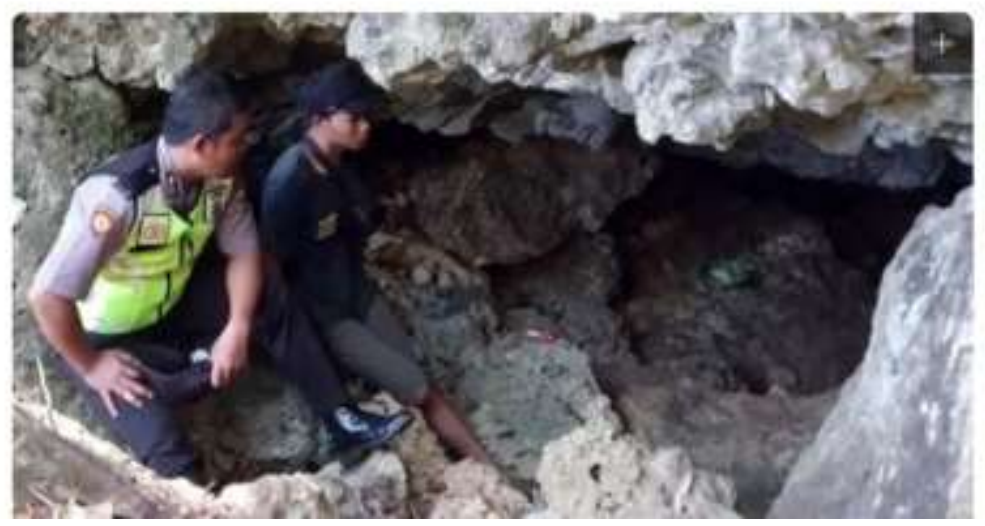

Figure 1. News in Mass Media on the Discovery of Mbangsri Cave

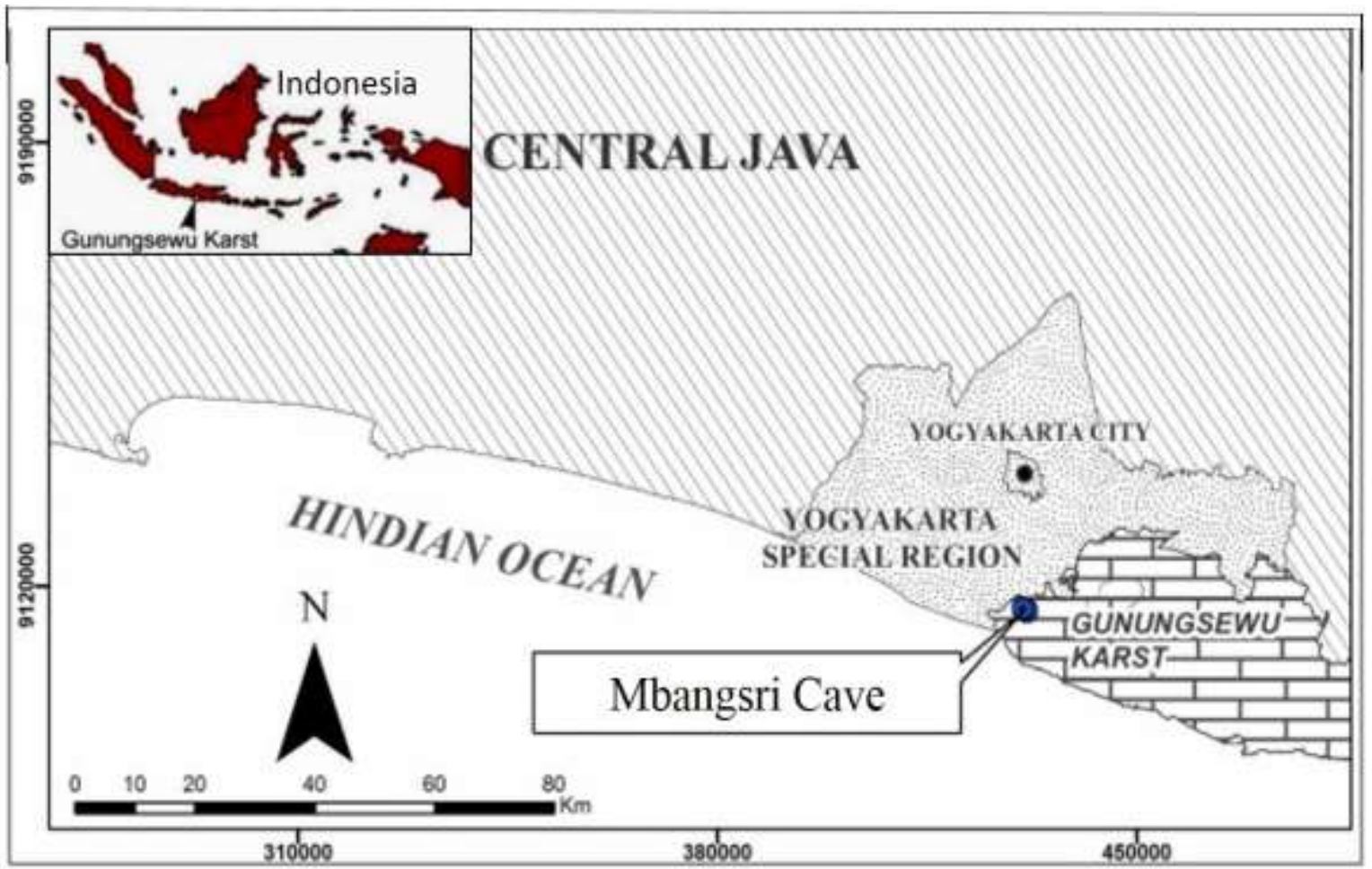

Figure 2. Map of Mbangsri Cave in the Gunungsewu Karst Area 


\section{RESULTS AND DISCUSSION}

The Gunungsewu karst area is divided into several hydrogeological subsystems with distinctive features [8]. Mbangsri Cave is located in the Panggang hydrogeological subsystem in the westernmost part of the Gunungsewu karst area [9]. Many springs with generally small discharge are distributed in the northern, western, and southern parts of the subsystem. The groundwater flows to the north, west, and south [10]. Typically, springs flowing to the north (like in the case of Mbangsri Cave) release small discharge that drops in dry seasons $[11,12]$.

Delineation on remote sensing images captured by UAV (Figure 3) showed that the catchment area of Mbangsri Cave was approximately 18.40 ha. It also presented the shape of a closed basin or doline. In this catchment area, Mbangsri Cave functions as a ponor or drainage conduit for rainwater.

The measurement in a sump, i.e., a passage that is submerged, revealed that there was no water flowing inside Mbangsri Cave. This finding demonstrates that the sump is a static pool. Also, the absence of water flow represents low water resource potentials in the cave.

The cave mapping categorized Mbangsri Cave as a single conduit (Figure 4). Geologically speaking, it began to develop in a fault with the dominant flow process. This formation is apparent from the mouth of the cave that is shaped like a funnel with a sharp bottom toward the water table $[13,14,15]$. The total length of the cave passage is $677.08 \mathrm{~m}$. The mapping process did not find other branches, meaning that, hydrologically, the cave does not receive water recharge from other caves. The water resource in Mbangsri Cave is a static pool that flows shortly after the rain on the surface. The maximum vertical distance to the surface of the karst area is merely $26 \mathrm{~m}$, indicating that the water storage above it is composed of a thin layer. This condition leads to a small diffuse flow from the epikarst zone [16, 17].

Figure 5 illustrates the geological conditions of Mbangsri Cave reconstructed by modifying the results in Nurjanah and Setianto (2016)[18]. It shows that the conduit development of Mbangsri Cave is situated at the point of contact between packstone and wackestone. The presence of Poyahan Fault causes the water to flow northward and prevents the cave from receiving water recharge from a wider area. It further validates the finding that Mbangsri Cave is solely located in the epikarst zone and, therefore, has small diffuse flow, as reflected from the stagnant underground river.

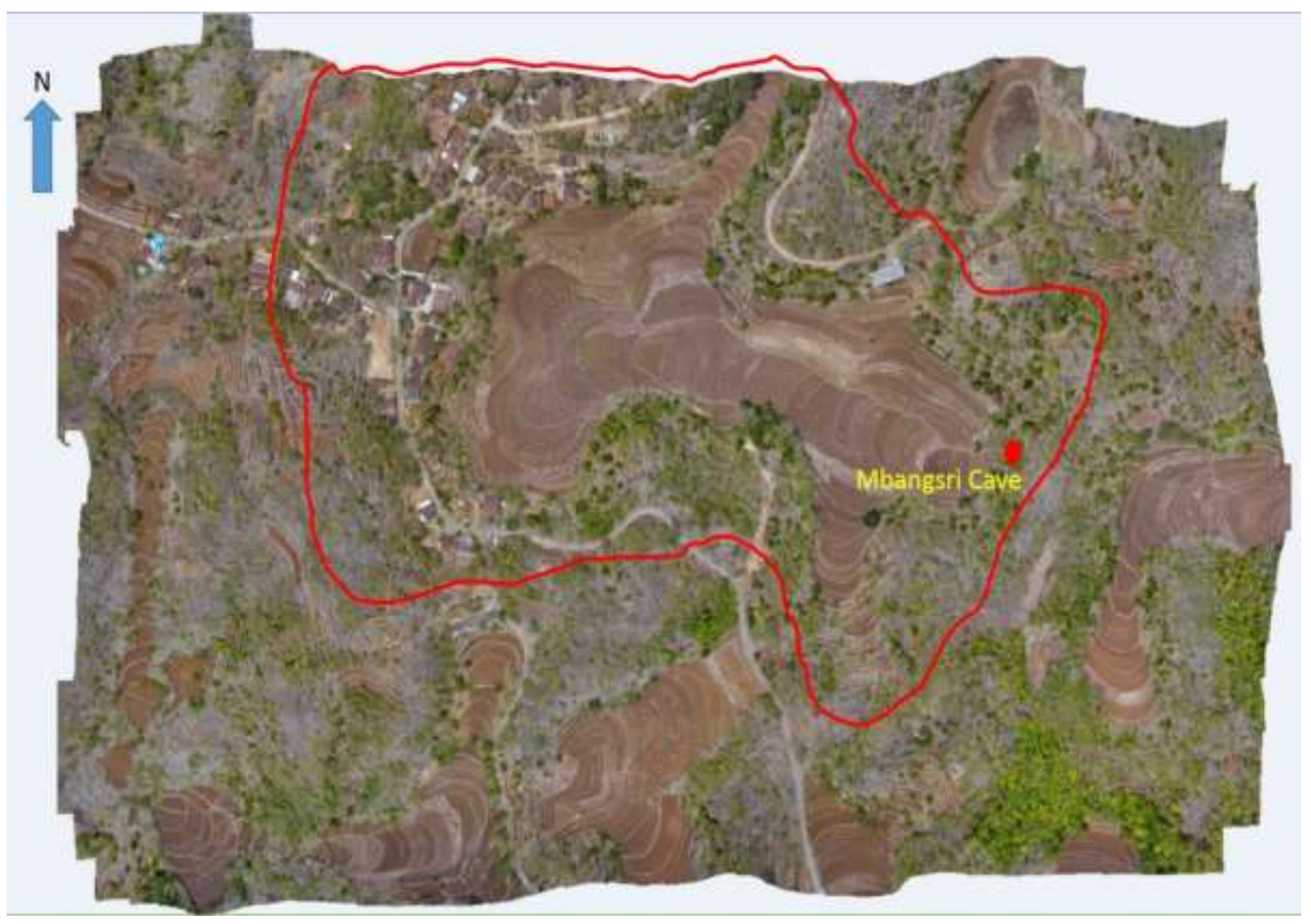

Figure 3. Delineated Boundary of the Surface Catchment Area of Mbangsri Cave 
These findings are in line with Rahmawati (2008) [19], Ramadhan (2019) [20], and Naufal (2019) [21] that specifically study the development stage of the karst area in the Panggang subsystem from Guntur Spring (2 km west of the research site). This spring has similar characteristics to those of Mbangsri Cave in that it is located in the same hydrogeological subsystem, groundwater flow direction, and formation, i.e., at the point of contact between packstone and wackestone [12,
18]. These studies claim that diffuse flow rapidly decreases after the rainy season. The spring water even barely flows during the dry season due to the small discharge [22, 23]. Ramdhani (2014) [23], Bahtiar (2015) [24], Adji et al. (2016, 2017) [25, 26] also report a similar result from the analysis of Petoyan Spring (1 km south of Mbangsri Cave). Aside from the narrow catchment area, small discharge is attributable to the thin epikarst layer.

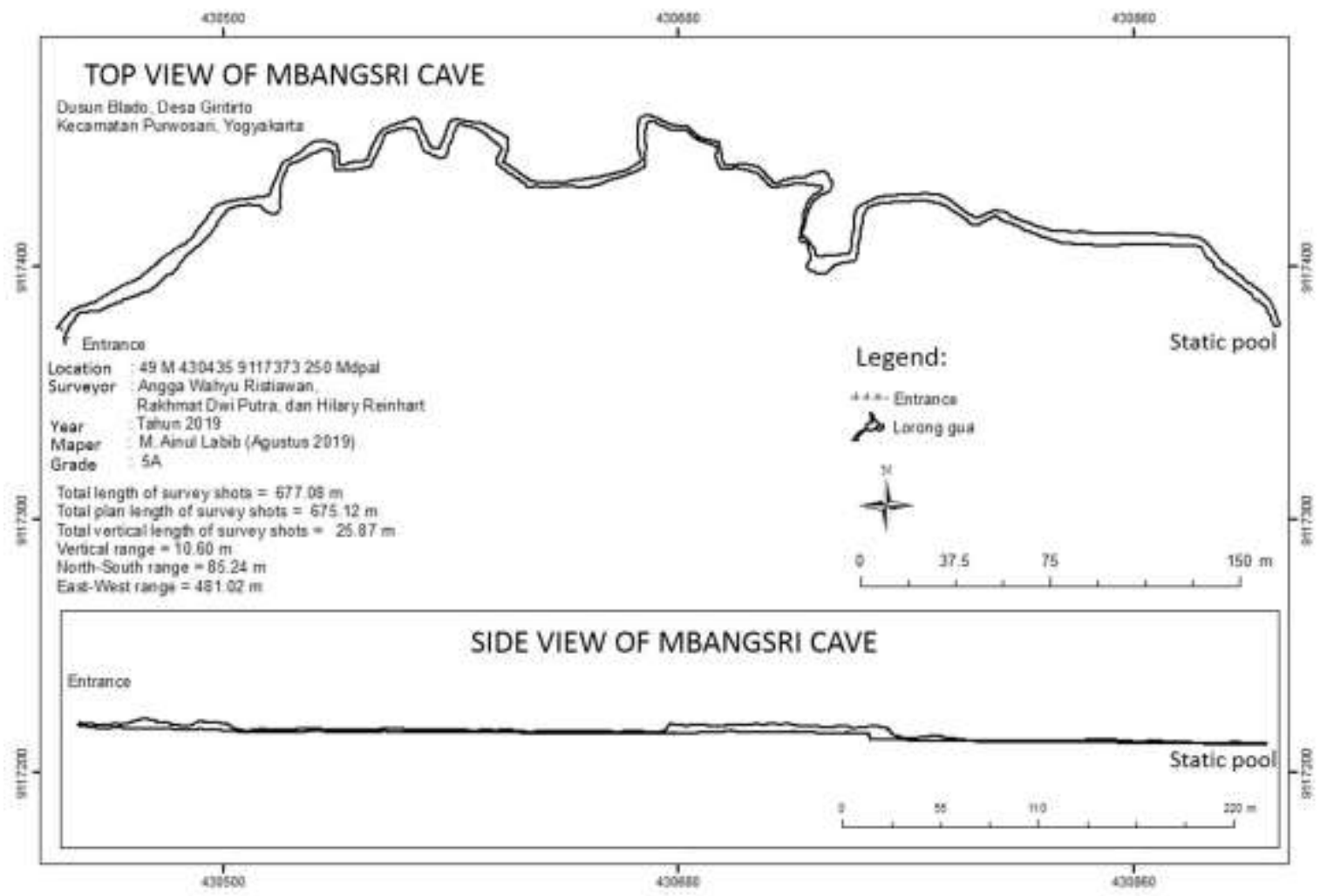

Figure 4. Map of Mbangsri Cave

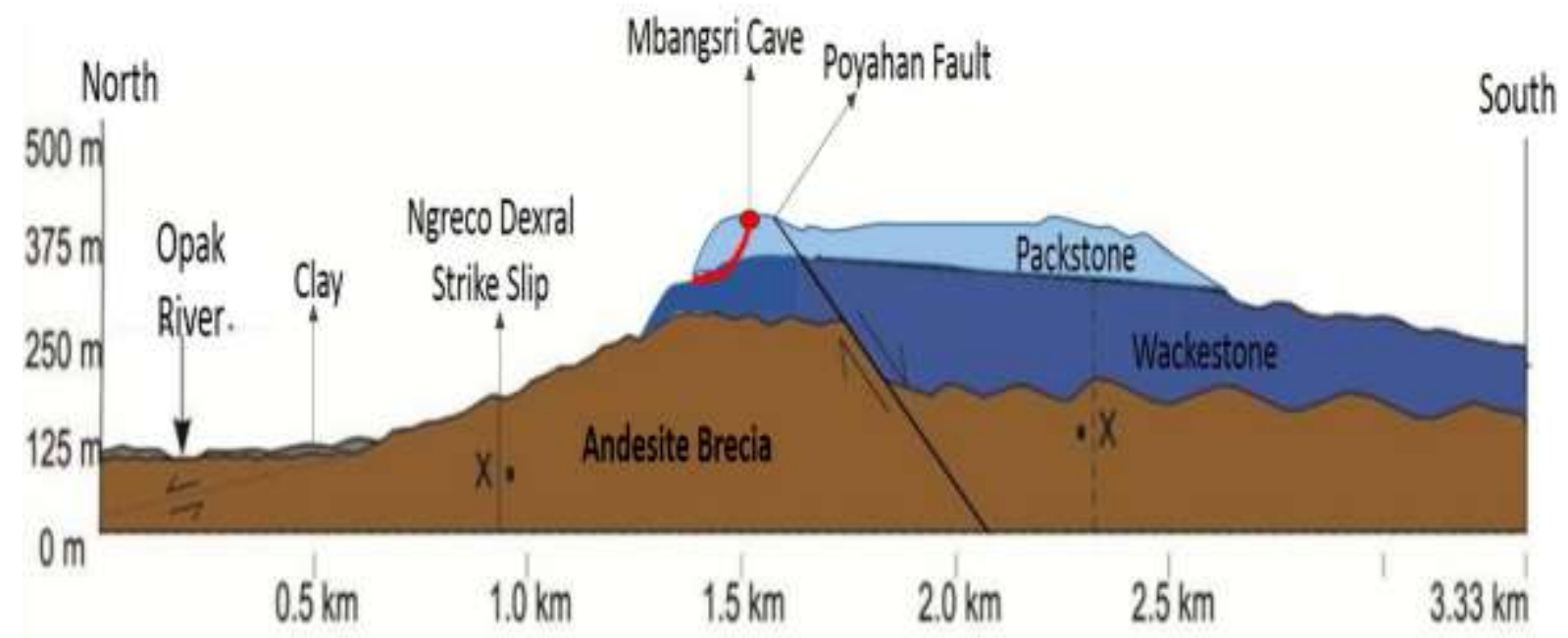

Figure 5. The Geological Cross Section of Mbangsri Cave (Modified from Nurjanah and Setianto, 2016 [18]) 


\section{CONCLUSIONS}

Based on the hydrogeological analysis, Mbangsri Cave has considerably low water resource potential. The causative factors include (1) narrow catchment area, (2) the presence of a fault in the south of the cave, blocking groundwater recharge from other regions, and (3) thin epikarst layer that contributes to the small diffuse flow. The water available in this cave is merely a static pool without any underground river flow.

\section{REFERENCES}

[1] Ford, D. and Williams, P. Karst Hydrology and Geomorphology. Chichester, West Sussex: John Wiley and Sons, Ltd, 2007.

[2] Gilli, E. Karstology - Karst, Caves and Springs: Elements of Fundamental and Applied Karstology. Boca Raton: CRC Press, 2015.

[3] Widyastuti, M., Cahyadi, A., Adji, T.N., Purnama, S., Firizqi, F., Naufal, M., Ramadhan, F., Riyanto, I.A., and Irshabdillah, M.R. 2019. Kualitas Air Sungai-sungai Alogenik di Kawasan Karst Gunungsewu, Kabupaten Gunungkidul pada Musim Kemarau. Proceeding of The Thrid National Seminar on Geography. Yogyakarta: Geography Graduated Program, Faculty of Geography, Universitas Gadjah Mada.

[4] Cahyadi, A. Peran Telaga dalam Pemenuhan Kebutuhan Air di Kawasan Karst Gunungsewu Pasca Pembangunan Jaringan Air Bersih. Geomedia, 14(2), 2016, pp. 23-33.

[5] Fatchurohman, H. and Cahyadi, A. Strategi Adaptasi Masyarakat Terhadap Bencana Kekeringan di Kawasan Karst Kecamatan Panggang, Gunungkidul. in Sudarmadji; Haryono, E., Adji, T.N., Widyastuti, M., Harini, R., Nurjani, E., Cahyadi, A. and Nugraha, H. (Eds). Ekologi Lingkungan Kawasan Karst Indonesia. Yogyakarta: Deepublish, 2011.

[6] Brunsch A, Adji, TN, Stoffel D, Ikhwan M, Oberle P, and Nestmann F. Hydrological assessment of a karst area in Southern Java with respect to climate phenomena. Proceeding of Asian Trans-Disciplinary Karst Conference. Yogyakarta: Faculty of Geography, Universitas Gadjah Mada, 2011.

[7] Worthington, S.R.H. Management of Carbonate Aquifers. In van Beynen, P.E. (ed). Karst Management. Dordrecht: Springer, 2011.

[8] Haryono, E. Introduction to Gunungsewu Karst. Field Guide of Asian Trans-
Disciplinary Karst Conference. Yogyakarta: Karst Research Group, Faculty of Geography, Universitas Gadjah Mada, 2011.

[9] Kusumayudha, S.B., Setiawan, J., Ciptahening, A.N., and Septianta, P.D. Geomorphologic Model of Gunungsewu Karst, Gunung Kidul Regency, Yogyakarta Special Territory, Indonesia: The Role of Lithologic Variation and Geologic Structure. Journal of Geological Resource and Engineering, 1, 2015, pp. 1-7.

[10] Hayono, E., Barianto, D.H., and Cahyadi, A. Hidrogeologi Kawasan Karst Gunungsewu: Panduan Lapangan Fieldtrip PIT PAAI ke-2. Yogyakarta: Association of Groundwater Experts (Perhimpunan Ahli Airtanah Indonesia/ PAAI), 2017.

[11] Notosiswoyo, S., and Kusumayudha, S.B. Hydrogeology of The Gunungsewu Karstic Area, Central Java, Indonesia: A Conceptual Model. Proceeding of Ninth Regional Congress on Geology, Mineral and Energy Resources of South East Asia. Kuala Lumpur, 1998.

[12] Cahyadi, A., Riyanto, I.A., Adji, T.N., Tivianton, T.A., Agniy, R.A., Ramadhan, F., Naufal, M., and Saputro, T.C. Hidrostratigrafi dan Dampaknya pada Kemunculan Mataair di Sub-Sistem Panggang, Kawasan Karst Gunungsewu, Kabupaten Gunungkidul. Proceedings of National Seminar on Geografi II. Yogyakarta: Faculty of Geography UGM, 2018.

[13] White, W.B. Geomorphology and Hydrology of Karst Terrains. New York: Oxford University, 1988.

[14] Palmer, A.N. Dynamics of Cave Development by Allogenic Water. Acta Carsologica, 30(2), 2001, pp. 13-32.

[15] Palmer, A.N. Cave Geology. Dayton, Ohio: Caves Books, 2007.

[16] Adji, T.N. Pemisahan Aliran Dasar Bagian Hulu Sungai Bribin pada Aliran Gua Gilap, di Kars Gunungsewu, Gunung Kidul, Yogyakarta. Jurnal Geologi Indonesia, 6 (3), 2011, pp. 165-175.

[17] Adji, T.N. Wet Season Hydrochemistry of Bribin Cave in Gunungsewu Karst, Indonesia. Environ Earth Sciences, 67, 2012, pp. 15631572.

[18] Nurjanah, Y. and Setianto, A. Pemetaan Kerawanan Gerakan Massa dengan metode Frequency Ration Daerah Kecamatan Kretek, Pundong dan Purwosari, Kabupaten bantul dan Kabupaten Gunungkidul, Daerah Istimewa Yogyakarta. Research Report. Yogyakarta: Faculty of Engineering, Universitas Gadjah Mada, 2016. 
http://mitgeo.ft.ugm.ac.id/2016/10/26/pemeta an-kerawanan-gerakan-massa-denganmetode-frequency-ratio-daerah-kecamatankretek-pundong-dan-purwosari-kabupatenbantul-dan-kabupaten-gunung-kidul-daerahistimewa-yogyakarta/

[19] Rahmawati, N. Karakterisasi Akuifer Karst atas Dasar Sifat Aliran dan Respon Debit Mataair Guntur, Girijati, Purwosari, Gunungkidul, DIY. Bachelor Thesis. 2019, Faculty of Geography, Universitas Gadjah Mada.

[20] Ramadhan, F. Hubungan Karakteristik Aliran dengan Hidrogeokimia Mataair Guntur di Kawasan Karst Gunungsewu. Bachelor Thesis. 2019, Faculty of Geography, Universitas Gadjah Mada.

[21]Naufal, M. Karakteristik Perkembangan Akuifer Karst Gunungsewu Melalui Analisis Master Recession Curve (MRC). Bachelor Thesis. 2019, Faculty of Geography, Universitas Gadjah Mada.

[22] Riyanto, I.A., Cahyadi, A., Adji, T.N., Haryono, E., Widyastuti, M., Agniy, R.F., Fathoni, W.A., Rahmawati, N., \& Baskoro, H. Analisis Konektivitas dan Karakterisasi Pelorongan dengan Uji Perunutan pada Mataair Epikarst Sub-sistem Panggang, Kawasan Karst Gunungsewu. Proceedings of the Annual Scientific Week organized by Association of Groundwater Experts (Perhimpunan Ahli Airtanah Indonesia/ PAAI). Bandung: ITB Press, 2018.

[23] Riyanto, I. A., Cahyadi, A., Ramadhan, F., Naufal, M., Widyastuti, M., and Adji, T. N.. Dampak Siklon Tropis Savannah pada Karst Window Kalinongko, Karst Gunungsewu, Kabupaten Gunungkidul, Indonesia. Jurnal Geografi : Media Informasi Pengembangan dan Profesi Kegeografian, 17(1), 2020, pp. 714.

[24] Ramdhani, M.A.A. Studi Neraca Air dalam Menentukan Daerah Tangkapan Air (DTA) Mataaair Karst (Studi Kasus Matair Ngeleng, Giritirto, Purwosari, Gunungkidul). Undergraduate Thesis. 2014, Faculty of Geography, Universitas Gadjah Mada.

[25] Bahtiar, I.Y. Kajian Respon Debit Mataair Ngeleng terhadap Curah Hujan untuk Karakterisasi Akuifer Karst. Undergraduate Thesis. 2015, Faculty of Geography, Universitas Gadjah Mada.

[26] Adji, T.N., Haryono, E., Fatchurohman, H. and Oktama, R. Diffuse Flow Characteristics and Their Relation to Hydrochemistry Conditions in The Petoyan Spring, Gunungsewu Karst, Java, Indonesia. Geosciences Journal, 20(3), 2016, pp. 381390.
[27] Adji, T.N., Haryono, E., Mujib, A., Fatchurohman, H. and Bahtiar, I.Y. Assessment of aquifer karstification degree in some karst sites on Java island, Indonesia. Carbonates Evaporites, 34(1), 2017, pp. 5366. 